VOL. V, FASC. 1 E 2, P. 151-178

\title{
NOVAS CONTRIBUICÕES AO ESTUDO DA ENTRADA DA BARRA DE CANANÉIA
}

(RECEAIDO EM $27 / \times 1 / 54$ )

\author{
Viktor Sadowsky
}

No presente trabalho damos publicidade às observações mais recentes que efetuamos na região da entrada da barra de Cananéia. Tendo trabalhado no assunto a partir de maio de 1952 , pudemos apresentar nas páginas dêste Boletim (1952, p. 201-211 e 1953, p. 191-214) as primeiras observações sistemáticas alí realizadas. Nêsses primeiros estudos relatamos o desenvolvimento dos fenômenos de ataque às margens do canal de entrada do sistema lagunar, linhas de costa adjacentes às duas ilhas formadoras do referido canal, e, ainda, os deslocamentos de materiais móveis observados na regi ão. 0 segundo ano de nossas pesquisas de campo foi dedicado não sòmente ao registro e à análise das modificações sobrevindas na linha de costas da região, como tambem para o estudo de um importante e rápido processo de acumulação de areias no setor sul da barra. Trata-se da formação de uma nova illia arenosa contígua à planície da ilha do Cardoso, situada inicialmente a cerca de $1 \mathrm{~km}$ ao NE. da Ponta de Itacurussá e $300 \mathrm{~m}$ aproximadamente a NNW dos rochedos conhecidos pelo nome de "Moleques". Acompanhamos sistemáticamente o processo de crescimento dessa formação arenosa, 
denominada "Ilha Nova" pelo pessoal do nosso Instituto, tendo a feliz oportunidade de assistir à dinâmica do processo em todos os estágios de sua evolução, até a conjugação da ilha com um esporão de restinga que progrediu para o norte a partir da Ponta de Itacurussá. Mais do que isso, pelo mês de maio de 1954 pudemos verificar o represamento completo das águas situadas entre a nova restinga e a planície da Ilha do Cardoso, com a consequente formação de uma pequena e alongada laguna de restinga.

No decorrer de nossas últimas pesquisas foram também feitas observações, na medida do possível, sôbre os "canais de maré" que sulcam o semi-círculo de altos-fundos da barra servindo de escoadouro para as correntes de maré, os quais têm grande importância para a navegação regional, já que constituem as únicas vias de acesso ao porto de Cananéia.

Queremos lembrar que no decurso do último ano de pesquisas não nos limitamos a simples medidas puramente topográficas e a sondagens. Todos os prováveis fatôres determinantes dos fenômenos em curso foram observados, registrados e posttos em equação, com os meios ao nosso alcance, tais como: duração, fôrça e direção dos ventos, das vagas e arrebentações, a ação das marés, etc. Entretanto no presente èstudo damos publicidade apenas aos fatos observados, deixando para outra oportunidade a discussão das causas prováveis dos mesmos. Nêsse setor, aliás, muito temos a esperar dos minuciosos trabalhos que a Comissão para o Estudo e Construção do Porto de Cananéia rêm de iniciar na área em questão.

\section{I}

\section{MODIFICAÇÕES NA ENTRADA DA BARRA}

As modificações da linha costeira foram registradas seguindo o mesmo método usado no ano anterior. Os setores e os pontos permaneceram os mesmos, salvo alguns que foram ligeiramente deslocados, em consequência do desgaste da costa. Como se pode verificar pelos "croquis" a numeração dos pontos permanece inalterada. Para poder obter diferenças mais sensíveis, as medidas foram tomadas de dois em dois meses. Para as observações das modificações e movimentos do relêvo submarino da porção próxima da praia imersa, foi utilizado um cordel de 100 metros de comprimento subdividido em secções de 10 metros, uma sonda de mão e uma vara de bambú para os trechos de menos de 4 metros de profundidade. As is óbatas assim obtidas foram verificadas periodicamente. 


\section{COSTA DA ILHA COMPRIDA}

1) Primeiro Setor - A extremidade SW da Ilha Comprida -Ponta da Trincheira- continuou a sofrer uma intensa erosão já assinalada no ano passado. Êsse desgaste acabou repelindo definitivamente a porção da margem alta que formava um cabo proeminente. A intensidade do fenômeno pode ser avaliada se compararmos nossas observações com as de João Dias da Silveira (1952), feitas pouco antes de iniciarmos nossas pesquisas; à p. 128 de seu trabalho lemos: "Podem ser observados nas costas ocidentais da Ilha Comprida, particularmente na parte Sul, "cliffs" com 8 metros de abrupto". Esse autor está se referindo, sem a menor dúvida, a êste trecho da ilha, cujas alturas atualmente não atingem nem a metade da medida a ssinalada. A margem tendo recuado formou-se uma concavidade aberta para o W e protegida por uma pequena praia que anula a ação das ondas. A porção da margem alta, ainda de pé no ano passado, foi destruida deixando em seu lugar um alto-fundo seguido de uma praia.

2) Segundo Setor - Esta parte da margem da entrada do canal, não sofreu alterações aprecíaveis. Comparando porém os resultados das medições obtidas no decurso dêste ano com os dados do ano anterior, nota-se uma tendência para a ruptura do equilíbrio que provàvelmente irá causar. num futuro próximo, um processo de desgaste da margem nêsse setor. Êsse desequilíbrio está sendo preparado por um fato novo -o transporte progressivo dos grandes depósitos de materiais móveis que aí se achavam acumulados, Y. Sadowsky (1953, foto p. 193), formando uma alta e extensa praia. Atualmente observa-se o deslocamento de grandes volumes dessa areia, a ponto de deixar descobertos blocos de "piçarras", que até então não eram visíveis. Já no fim do ano passado as vagas da maré enchente conseguiam por vêzes alcançar a base da falésia, desgastando-a. 0 deslocamento dos elementos móveis da praia, assinalados acima, pôde ser observado desde o in ício dêste ano, com direção predominante para o $W$, isto é, em direção ao setor $n^{\circ} 1$, onde se acumulam parcialmente em frente da Ponta da Trincheira, formando uma pequena língua de areia submersa.

As profundidades vizinhas da praia, nêsse setor, não sofreram al terações dignas de nota.

3) TERCEIRo SETOR - Êste setor compreende apenas uma pequena enseada e acha-se virtualmente fora do canal de entrada, conforme se pode verificar pelo "croquis", e está sempre sujeito a uma erosão enérgica, da qual não escapa igualmente sua praia.

Quanto à faixa fronteirín de nar pôde-se verificar pelas 


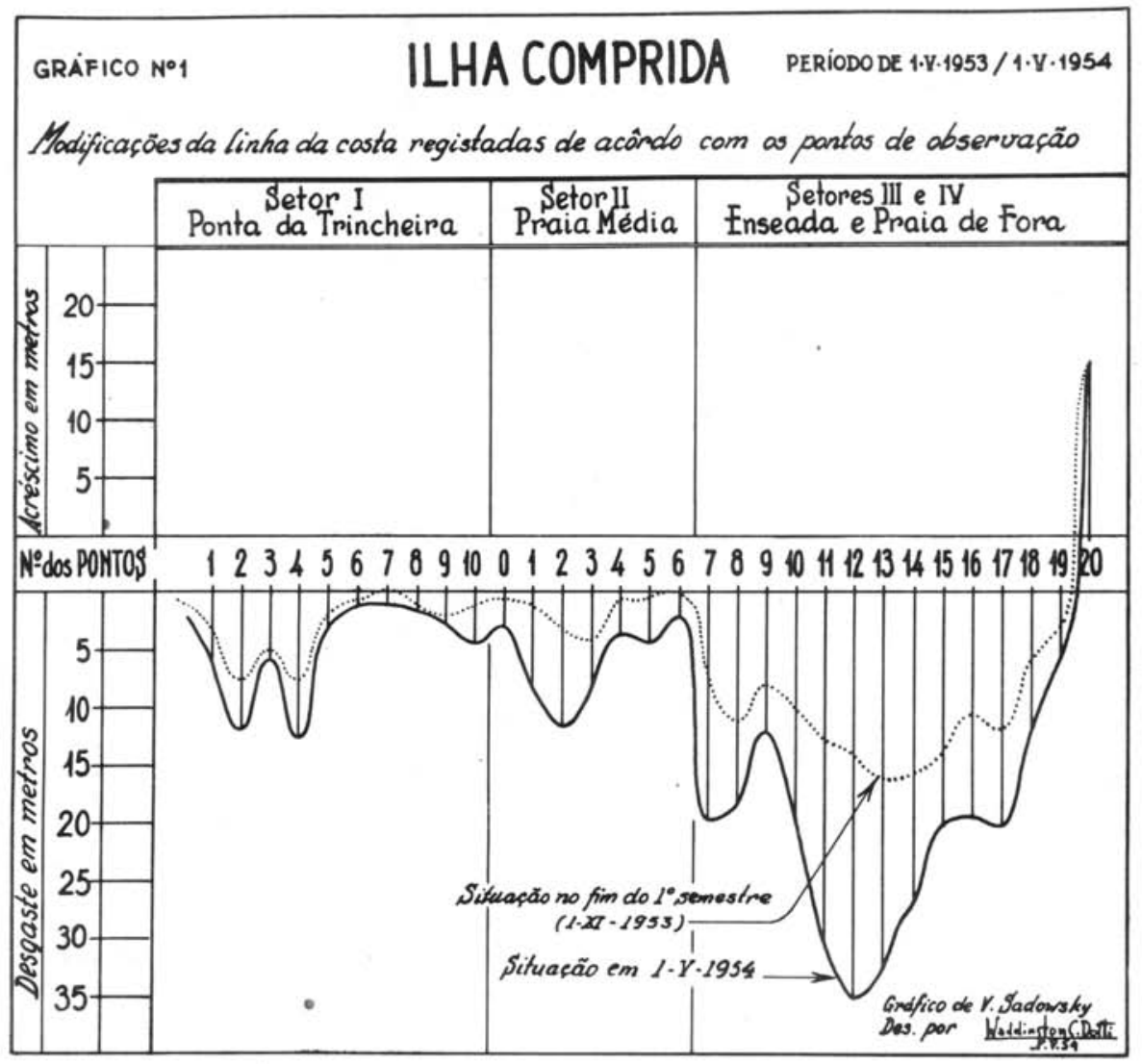

sondagens periódicas que existe um aumento médio da profundidade de cêrca de $0,50 \mathrm{~m}$ por ano.

4) QuARTo SEToR - Êste último setor engloba a porção SE da Ilha Comprida, incluindo o Pontal de Fora. A partir da fronteira do setor $\mathrm{n}^{\circ} 3$ até o início do Pontal de Fora, o registro das modificações da linha costeira demonstrou uma erosão muito acentuada. Esse desgaste é favorecido pela própria constituição dêsse trecho da ilha que nada mais é do que uma língua de areia, comportando apenas uma fraca vegetação pioneira muito recente. Se existe uma base mais resistente de "piçarras", o que parece pouco provável, essa camada é em todo caso bastante profunda para não exercer nenhuma influência sôbre as camadas de areias superiores.

A extremidade SE da ilha - o Pontal de Fora - durante o período de observação progrediu sensìvelmente em direção a ESE, em consequência da acumulação de grandes contingentes de areia arrastados 
ILHA COMPRIDA

Modificaços observadas na costa, calculadas em decimetros

\begin{tabular}{|c|c|c|c|c|c|c|c|}
\hline \multicolumn{5}{|c|}{1953} & \multicolumn{3}{|c|}{1954} \\
\hline Nos. & V-VI & VII-VIII & IX-X & XI-XII & I-II & III-IV & TOTAL (12 moses) \\
\hline 1 & 0,70 & 1,40 & 1,60 & 0,50 & 0,40 & 1,10 & $5,70=$ \\
\hline 2 & 0,60 & 0,60 & 4,30 & 2,50 & 2,20 & 1,60 & $11,80=$ \\
\hline 3 & 2,40 & 0,70 & 2,10 & 0,10 & \pm 0 & 0,20 & $5,50 \equiv$ \\
\hline 4 & 2,50 & 2,80 & 3,30 & 1,80 & 0,40 & 1,80 & $12,60=$ \\
\hline 5 & 0,10 & 0,80 & 1,10 & 0,40 & 0,20 & 0,50 & $3,10 \mathrm{~m}$ \\
\hline 6 & \pm 0 & 0,20 & 0,60 & \pm 0 & \pm 0 & 0,20 & $1,00 \equiv$ \\
\hline 7 & \pm 0 & \pm 0 & \pm 0 & \pm 0 & 0,90 & 0,50 & $1,40 \mathrm{~m}$ \\
\hline 8 & 0,50 & 0,40 & 0,40 & \pm 0 & \pm 0 & 0,20 & $1,50 \mathrm{~m}$ \\
\hline 9 & \pm 0 & \pm 0 & 2,00 & \pm 0 & \pm 0 & 0,85 & $2,85=$ \\
\hline 10 & \pm 0 & 0,30 & 1,10 & \pm 0 & \pm 0 & 2,80 & $4,20=$ \\
\hline 0 & 0,20 & \pm 0 & 0,50 & 0,60 & \pm 0 & 1,50 & $2,80=$ \\
\hline 1 & \pm 0 & \pm 0 & 1,60 & $2, \infty$ & 2,40 & 2,40 & $8,40=$ \\
\hline 2 & \pm 0 & 0 & 3,80 & 2,20 & 1,10 & 4.50 & $11,60 \mathrm{~m}$ \\
\hline 3 & \pm & \pm & 4,40 & 0,40 & 1,10 & 2,60 & $8,50 \mathrm{~m}$ \\
\hline 4 & \pm 0 & 0 & 0,60 & \pm 0 & \pm 0 & 3,00 & $3,60 \mathrm{~m}$ \\
\hline 5 & \pm & \pm 0 & 0,50 & 0,20 & 1,30 & 2,20 & $4,20 \mathrm{~m}$ \\
\hline 6 & \pm 0 & \pm 0 & \pm 0 & 0,40 & \pm 0 & 1,70 & $2,10 \mathrm{~m}$ \\
\hline 7 & 1,20 & 1,80 & 4,60 & 2,10 & 2,40 & 7,70 & $19,80 \mathrm{~m}$ \\
\hline 8 & 1,60 & 4,40 & 5,20 & 1,00 & 2,10 & 4,30 & $18,60 \mathrm{~m}$ \\
\hline 9 & 2,10 & $3, \infty$ & 2,90 & 0,10 & 0,90 & 3,20 & $12,20 \mathrm{~m}$ \\
\hline 10 & 2,00 & 4,80 & 3,70 & 0,80 & 2,10 & 6,20 & $19,60 \mathrm{~m}$ \\
\hline 11 & 3,10 & 5,60 & 4,30 & 3,20 & 5,40 & 8,90 & $30,50 \mathrm{~m}$ \\
\hline 12 & 2,30 & 7,60 & 4,10 & 3,70 & 6,20 & 11,10 & $35,00 \mathrm{~m}$ \\
\hline 13 & 3,30 & 9,20 & 5,60 & 0,90 & 4,80 & 9,30 & $33,10 \mathrm{~m}$ \\
\hline 14 & 3,00 & 8,40 & 4,60 & 1,10 & 4,20 & 5,30 & $26,60 \mathrm{~m}$ \\
\hline 15 & 4,50 & 6,70 & 3,10 & 0,30 & 1,40 & 4,10 & 20,10 m \\
\hline 16 & 4,30 & 5,10 & 3,00 & 0,50 & 2,30 & 4,00 & $19,20 \mathrm{~m}$ \\
\hline 17 & 3,10 & 6,50 & 3,70 & \pm 0 & 2,90 & 3,80 & $20,00=$ \\
\hline 18 & 1,10 & 2,90 & 2,10 & 1,20 & 2,70 & 3,10 & $13,10 \mathrm{~m}$ \\
\hline 19 & \pm 0 & 2,50 & 0,70 & \pm & 0 & 2,10 & $5,30 \mathrm{~m}$ \\
\hline 20 & $+4,20$ & $+2,80$ & $+9,00$ & $+1,10$ & +2 & $-4,10$ & $+15,00=$ \\
\hline
\end{tabular}


da parte adjacente da praia externa da Ilha Comprida (Praia de Fora), em direção ao S. Êste movimento de transporte das areias para o S só se observa na parte da Praia de Fora vizinha ao Pontal e parece ser a consequência de um regime de correntes secundárias, que se torna muito complicado pelos movimentos tumultuosos e desordenados resultantes da refração do marulho, o qual, na sua marcha em direção à costa, choca-se com a parte externa dos altos- fundos da barra, provocando nêste local uma extensa zona de arrebentações. Outro fator importante é a influência das correntes de maré.

Em relação à praia externa (Praia de Fora), orientada para NE, e fora da influência imediata das correntes da barra, parece, de acôrdo com as observações feitas, que o deslocamento dos materiais móveis acha-se vinculado à direção dos ventos dominantes. Isto significa que o marulho provocado pelos ventos do quadrante $S$, e as correntes que daí resultam, arrastam a areia para o N. Por outro 1 ado, os ventos dos quadrantes $\mathrm{E}$ e NE têm uma ação inversa, o que faz com que os pescadores locais, na sua singela terminologia, digam que, quando os ventos sopram do $\mathrm{S}$, "a água corre para leste", isto é para NE, visto que a Praia de Fora tem uma direção geral para NE, e quando os ventos sopram de NE ou E, "a água corre para o sul" (*). Os deslocamentos das areias seguem efetivamente essa regra, porém como os ventos do $\mathrm{S}$ são dominantes e sobretudo como as marulhadas fortes provêm principalmente dêsse quadrante, os deslocamentos maciços parecem efetuar-se ao longo da Praia de Fora, isto é, sôbre uma extensão de mais de $74 \mathrm{~km}$ na direção de NE, até alcançar a Barra de Icapara, onde o pontal da ilha está constantemente avançando para NE. Tôdas as embocaduras dos riachos que desaguam na praia acham-se orientadas igualmente para NE, o que confirma o fenômeno observado.

\section{COSTA DA ILHA DO CARDOSO}

Como se percebe fàcilmente pelo exame dos "croquis" da região, no trecho estudado, existem duas zonas muito diferentes. A primeira compreende as margens meridionais do canal de entrada, a partir do vértice geodésico denominado "Chapeleiro", até a Ponta do Perigo. A segunda inicia-se na Pontá do Perigo, em direção ao S, até às

(*) - Essas correntes secundárias, geradas pelos ventos, influem notàvelnente sôbre o regime de marés do sistema lagunar, perturbando bastante a regularidade do fenômeno. Veja-se também o que escreve Clodomiro Pereira da Silva (1940, p. 81) sôbre essa regièo. 
proximidades da Ponta de Itacurussá. As duas porções estão localizadas na extremidade NE da Ilha do Cardoso. Essa parte da ilha é tìpicamente uma planície de restingas, notando-se a ausência de "piçarra" nas camadas inferiores, ao contrário do que acontece na I lha Comprida. Sua origem é relativamente recente e é devida à colmatagem pelos produtos de erosão, principalmente areia marinha. 0 caráter de suas margens difere, de um modo geral, do da Praia de Fora, que apresenta o dispositivo típico das grandes praias submetidas à ação direta do oceano, isto é, uma praia muito larga, de areia nua, seguida por uma zona de vegetação pioneira, psamófila e halófila, continuada por uma região de dunas cativas. Nessa porção da Ilha do Cardoso encontramos um terreno de caráter bem diferente, sendo baixo, arenoso e recoberto por uma vegetação bastante densa do tipo "brousse" (mata do jundú, segundo alguns autores - F. Rawi tscher, 1944, p. 24). Com efeito, o jundú chega até o bordo superior da praia, que é aqui bem mais estreita do que a Ilha Comprida. Note-se que as duas praias são topogràficamente a continuação uma da outra, porém as condições de ataque pelas grandes marulhadas e pelos ventos são completamente diferentes, sendo que a ação dinâmica das vagas acha-se aqui fortemente a tenuada pela auréola dos al tos-fundos externos da barra. Com relação ao papel importante que os altos-fundos exercem sôbre a propagação das ondas podemos citar A.Guilcher (1950, p. 120): "Ici, ce n'est pas l'influence d'un obstacle qui dépasse la surface de l'eau, mais celle du fond qui joue."

Como acabamos de dizer acima, existem na Ilha do Cardoso dois alinhamentos, um partindo da Ponta do Perigo em direção ao W, o outro, da mesma ponta, em direção ao S. 0 primeiro dêsses alinhamentos segue a margem $S$ do canal, o segundo a praia externa da parte baixa da Ilha do Cardoso.

1) Prineiro setor - (Margem $S$ do canal de entrada) - Esta parte da costa, durante o segundo ano, não sofreu grandes modificações. Os movimentos observados tiveram mais um caráter de pulsação do que pròpriamente de modificação permanente. Isto é, segundo a amplitude maior ou menor das marés, intensidade e incidência do marulho, $\left(^{*}\right)$ a praia dêsse setor aumentava ou diminuia de acôrdo com as contribuições ou carreamento dos materiais móveis, o que fazia voltar a linha da praia ao seu estado anterior, sem deixar modificações mais duradouras. Na parte submersa fronteiriça, as sondagens efetuadas no fim do segundo ano demonstraram não haver continuação do processo

(*) - Sôbre êsse assunto veja-se também a oarta II que acompanha o trabalho do Comte. Paulo de Castro Moreira da Silva (1952). 


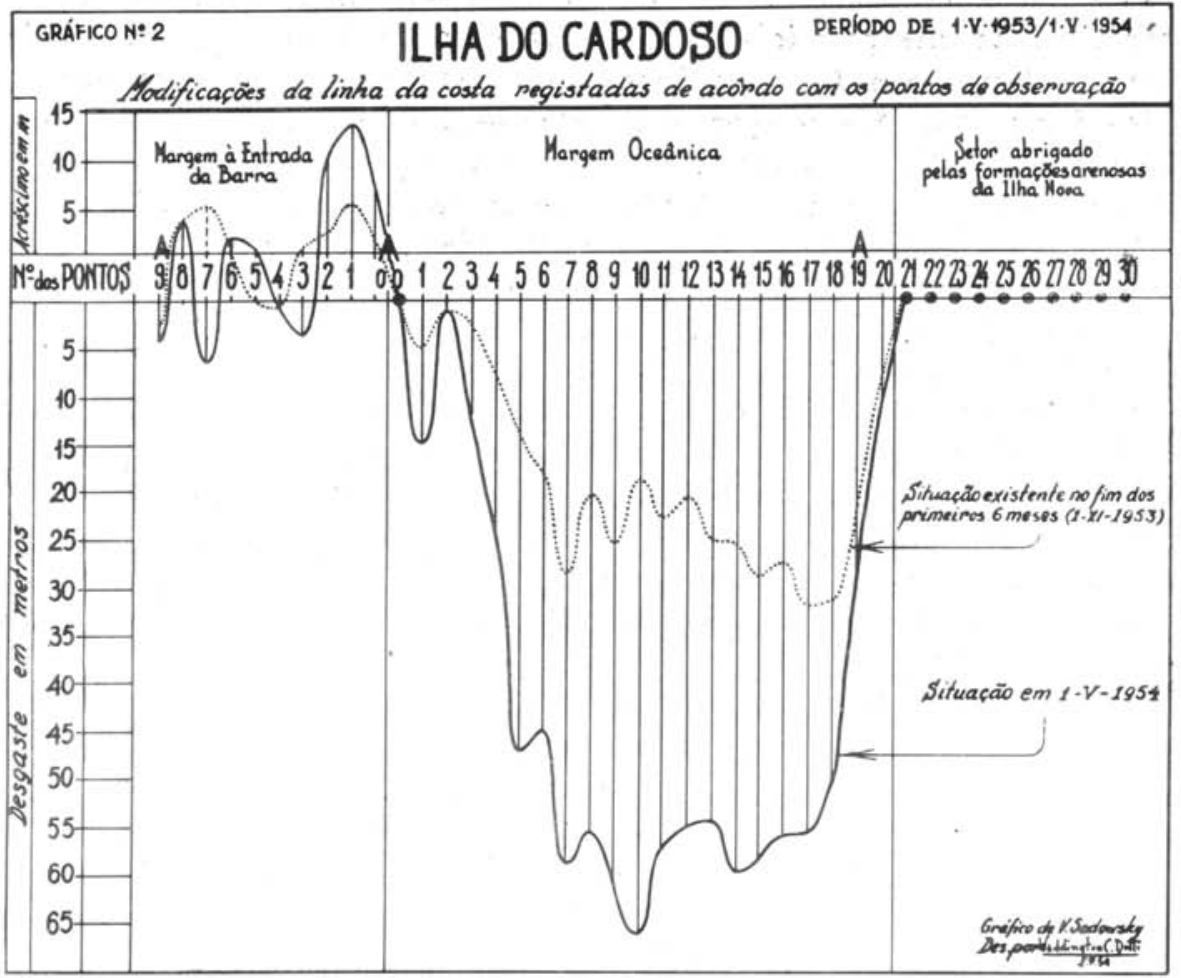

de assoreamento que havia sido assinalado no primeiro ano.

2) SEGUNDO SETOR - Êsse setor, representado principalmente pela nargem NW da Ponta do Perigo, é o que permaneceu, no decorrer dêstes dois anos, como único trecho da região da barra onde se verifica uma acumulação constante de materiais móveis.

0 crescimento lento e regular dêste ponto, do mesmo modo que o assoreamento da parte submersa fronteiriça, não se acham em proporção com os volumes sempre crescentes dos produtos do desgaste observado em outras partes da Ilha do Cardoso. Êsse desgaste se traduz pelo transporte de milhares de metros cúbicos de areia em direção ao N, (V.Sadowsky 1953, p. 212), porém não nos foi possível determinar para onde se dirige êsse enorme volume de materiais. Um problema semelhante foi recentemente discutido por A.Guilcher e J.P.Nicolas (1954, p. 236) sem que pudessem êsses autores chegar a uma explicação satisfatória sôbre o movimento de areias nas costas do Senegal. 
ILHA DO CARDOSO

Modificacōes observadas na costa, calculadas em decimetros

\begin{tabular}{|c|c|c|c|c|c|c|c|}
\hline \multicolumn{5}{|c|}{1953} & \multicolumn{3}{|c|}{1954} \\
\hline No.. & $v-v 1$ & VII -VIII & $I X-X$ & XI-XII & $I-I I$ & III-IV & TOTAL (12 meses) \\
\hline 9 & 0,60 & 0,40 & 1,90 & 0,50 & $+1,00$ & 1,60 & $4,00 \mathrm{~m}$ \\
\hline 8 & $+2,30$ & $+2,70$ & 1,50 & $+0,40$ & $+2,10$ & 2,70 & $+3,30=$ \\
\hline 7 & $+2,00$ & $+5,90$ & 2,90 & 1,10 & 5,70 & 4,90 & $6,70 \mathrm{~m}$ \\
\hline 6 & $+0,20$ & $+0,20$ & 0,20 & $+0,40$ & $+1,00$ & 0,30 & $+1,30 \mathrm{~m}$ \\
\hline 5 & \pm 0 & $+0,30$ & 0,40 & 0,10 & $+0,60$ & 0,20 & $+0,20=$ \\
\hline 4 & \pm 0 & $+0,20$ & 0,70 & \pm 0 & $+0,20$ & 0,20 & $0,50=$ \\
\hline 3 & \pm 0 & $+0,30$ & $+0,70$ & $+0,50$ & \pm 0 & $+2, \infty$ & $+3,50=$ \\
\hline 2 & $\pm \quad 0$ & $+1,10$ & $+0,90$ & $+0,20$ & $+0,40$ & $+6,80$ & $+9,40=$ \\
\hline 1 & $+1,10$ & $+2,50$ & $+1,20$ & $+1,80$ & $+0,90$ & $+6,10$ & $+13,60=$ \\
\hline 0 & \pm 0 & $+0,60$ & $+1,40$ & $+2,10$ & $+1,20$ & $+1,50$ & $+6,80=$ \\
\hline 0 & \pm 0 & 0,40 & $+0,40$ & $+1,90$ & 4,10 & $+2,20$ & $\pm 0 m$ \\
\hline 1 & 2,10 & 1,80 & 1,10 & 5,40 & 2,50 & 2,40 & $15,30=$ \\
\hline 2 & 0,90 & $\pm \quad 0$ & 0,20 & 2,70 & $+1,20$ & $+1,50$ & $1,10=$ \\
\hline 3 & 1,50 & 0,50 & 1,40 & 3,40 & 1,80 & 3,80 & $12,40=$ \\
\hline 4 & 1,80 & 2,10 & 3,40 & 3,90 & 3,70 & 9,10 & $24,00 \mathrm{~m}$ \\
\hline 5 & 3,40 & 5,40 & 5,70 & 8,10 & 5,90 & 19,00 & $47,50=$ \\
\hline 6 & 4,10 & 3,40 & 9,80 & 6,20 & 4,30 & 17,70 & $45,50=$ \\
\hline 7 & 4,30 & 6,70 & 10,80 & 11,10 & 7,30 & 19,20 & $59,40 \mathrm{~m}$ \\
\hline 8 & 5,20 & 7,00 & 8,10 & 14,20 & 6,10 & 15,60 & $56,20 \mathrm{~m}$ \\
\hline 9 & 6,80 & 7,40 & 11,50 & 16,30 & 5,90 & 13,40 & $61,30=$ \\
\hline 10 & 4,10 & 5,30 & 9,10 & 14,50 & 7,80 & 26,40 & $67,20=$ \\
\hline 11 & 5,30 & 7,80 & 10,40 & 11,00 & 8,20 & 15,70 & $58,40 \mathrm{~m}$ \\
\hline 12 & 3,20 & 5,50 & 10,40 & 10,40 & 7,60 & 18,10 & $55,20=$ \\
\hline 13 & 5,10 & 7,60 & 12,60 & 6,30 & 5,70 & 17,50 & $54,80=$ \\
\hline 14 & 6,20 & 8,20 & 11,50 & 8,10 & 4,80 & 21,40 & $60,20=$ \\
\hline 15 & 8,90 & 8,10 & 12,50 & 8,50 & 4,70 & 15,70 & $58,40 \mathrm{~m}$ \\
\hline 16 & 8,60 & 8,70 & 10,30 & 4,10 & 5,00 & 19,50 & $56,20=$ \\
\hline 17 & 8,50 & 9,00 & 14,50 & 6,50 & 7,10 & 10,40 & $56,00 \mathrm{~m}$ \\
\hline 18 & 6,90 & 10,00 & 15,00 & 6,50 & 4,00 & 8,50 & $50,90 \mathrm{~m}$ \\
\hline 19 & 3,10 & 6,40 & 13,00 & 4,10 & 1,50 & 0,40 & $28,50 \mathrm{~m}$ \\
\hline 20 & 1,10 & 2,90 & 4,50 & 1,20 & 0,50 & 0,30 & $10,50=$ \\
\hline
\end{tabular}


3) Terceiro Setor - A parte norte dêsse setor, nos primeiros 250 metros a partir da Ponta do Perigo, sofreu modificações relativamente pouco importantes no decurso dêste ano. No fim do primeiro ano de observações haviamos observado, nêste ponto, um desgaste considerável que provocara o recuo da Ponta do Perigo para dentro do canal e, destarte, mudando o ângulo de incidência das ondas vindas de fora. Esse deslocamento processou-se de forma análoga ao observado na Ponta da Trincheira, do lado oposto do canal, na Ilha Comprida, até o fim do segundo ano.

No trecho seguinte, até o fim dêsse setor, continuou um processo de erosão sempre crescente. Esta parte era formada por um cordão costeiro, bastante baixo, porém evidentemente de formação mais antiga, pois se achava revestido de uma camada de 10 a $15 \mathrm{~cm}$ de terra vegetal recoberta por uma mata densa (mata do jundú), composta de árvores baixas, das quais algumas atingem a $38 \mathrm{~cm}$ de diâmetro de tronco, e de algumas palmeiras "jerivás", de 6 a $7 \mathrm{~m}$ de altura. Êsse cordão costeiro foi atacado pelo mar há pouco tempo (aproximadamente 3 anos), e já se acha completamente destruido em vários pontos. Existindo atrás dêsse cordão uma zona baixa e pantanosa, sulcada por alguns riachos que drenam as águas doces coletadas por essa parte baixa da ilha, por ocasião das marés al tas e mar agitado (principalmente com ventos do quadrante S), as ondas i rrompem até o intervalo entre os dois cordões sucessivos e a água do mar invade a zona baixa intermediária. Os riachos, lagôinhas e pântanos aí existentes tornam-se então salobros.

No mar, numa linha a 100 metros da praia, não foram observadas modificações notáveis. Isto parece demonstrar que, concomitantemente com o recuo da linha da praia, a profundidade das águas avança paralelamente e a curva de nível batimétrico permanece a mesma.

A observação da linha da praia externa da Ilha do Cardoso dusante dois anos revelou-nos, ainda, um outro fato bastante importante. Nessa praia, que mede aproximadamente $5 \mathrm{~km}$ da Ponta de It:icurussá à Ponta do Perigo, podia-se encontrar, nos primeiros me:ies de observação, em particular nos setores III e IV, numerosos seixos marinhos alcançando $5-6 \mathrm{~cm}$ de comprimento, de filito e mais raramente de quartzito, provenientes, sem a menor dúvida, do único afloramento dessa rocha existente na região - a Ponta de Itacurussá, na extremidade $S$ da praia. Com o desenvolvimento da neo-formação da "Ilha Nova", causadora de modificações no regime de correntes secundárias marginais, e que também provocou uma modificação no ângulo de incidência das vagas, a quantidade de seixos diminuiu progressivamente, tornando-se muito rara na metade do segundo ano, e desaparecendo completamente no fim dêsse ano. 
4) QUARTo SETOR - Êsse setor, sendo apenas o prolongamento do precedente, sofreu as mesmas modificações que a porção $S$ do III setor. 0 processo de erosão já observado de inicio intensificou-se repentinamente. Êsse aumento coincide com as rápidas e profundas modificações que se desenvolvem na parte $S$ da barra - aumento da "Ilha Nova" e fechamento do canal do S - como veremos mais adiante (vide "croquis" p. 168-69, fases 1-8). No seu crescimento de S para $\mathrm{N}$, a "Ilha Nova" exerceu progressivamente uma ação protetora sôbre o último trecho dêsse setor (pontos 20 a 17), atenuando assim o processo de desgaste que antes era bastante acentuado.

5) QUINTO SETOR - Estando êste setor completamente protegido pela neo-formação e achando-se fora da ação do marulho, seu comportamento segue uma marcha completamente inversa dos anteriores. Com efeito, constata-se um crescimento bastante rápido da praia e um assoreamento progressivo e acelerado da zona intermediária submersa, com depositos de lama nos pontos mais fundos, que se acham fora da ação das correntes de maré.

EXPLICAç̃̃o das tABELAS E FIGURAS - As tabelas representam o desgaste ou a acumulação verificadas durante o último ano de observações ao longo das costas da Ilha Comprida e Ilha do Cardoso, nos setores indicados pelo esquema da região (Fig. A). A primeira coluna indica o número dos pontos, de cada setor, na mesma ordem em que foram comentados no texto. Nas outras colunas estão computadas as modificações, para mais ou para menos, observadas, de dois em dois meses, em cada ponto. A última coluna a direita dá a soma dos acrescimos, negativos ou positivos, durante os 12 meses de observação. 0 sinal + antes dos números significa acrescimo positivo, i.é., acumulação; o sinal -, da mesma forma, significa desgaste. 0 sinal \pm 0 representa um ponto que se manteve mais ou menos estável, sem modificações apreciáveis.

No esquema da região (Fig. A), estão representadas gráficamente as modificações da costa por meio de linhas: - em pontilhado (situação em 30/IV/1952); - em tracejado (situação em 30/IV/1953) e, finalmente a situação em $30 / I V / 1954$, em linha contínua.

Os gráficos n० 1 e 2 traduzem os resultados das tabelas permitindo visualisar o progresso do desgaste ou acumulação nas zonas estudadas. A linha pontilhada indica a situação existente no fim do primeiro semestre. A linha contínua representa a situação em 1/V/1954. 


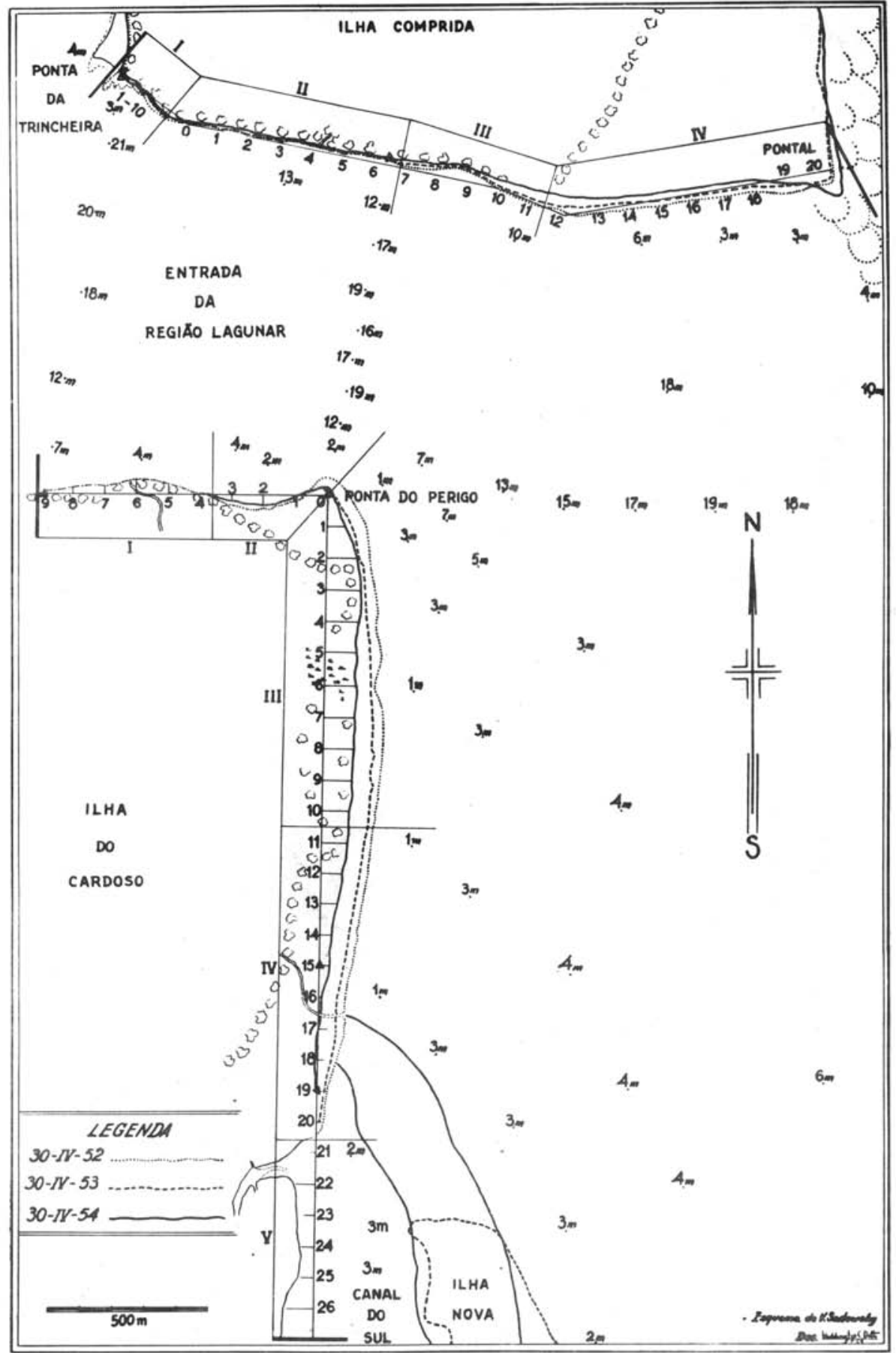

Fig. A 
Os altos-fundos da entrada da barra de Cananéia formam diante do canal que separa a Ilha Comprida da Ilha do Cardoso, um vasto semi-círculo irregular que se inicia defronte ao Pontal de Fora da Ilha Comprida e passa a $2 \mathrm{~km}$ aproximadamente a NW da Ilha de Bom Abrigo, recurvando-se em direção à Ponta de Itacurussá. Aproximadamente a $900 \mathrm{~m}$ a ENE desta úl tima encontram-se rochedos cristalinos (?) aflorantes, forçando arrebentações em pontos restritos, rochedos êsses, localmente conhecidos pelo nome de "Moleques". Entre os Moleques e a Ilha do Cardoso existia, antes do in ício dêste estudo, uma zona que, a despeito de sua pouca profundidade $( \pm 4 \mathrm{~m})$, não apresentava quaisquer áreas ou faixas de arrebentação. Nêsse ponto localizava-se, então, o principal canal de acesso para a entrada da região lagunar de Cananéia. Os navios, partindo do fundeadouro de Bom Abrigo, ou contornando essa ilha pelo W, passavam entre os Moleques e a praia externa da Ilha do Cardoso e, dando uma guinada para E, demandavam diretamente o canal de entrada da regi ão lagunar. Nessa época, a ENE dos Moleques encontravam-se extensas acumulações arenosas não aflorantes. Foi a partir dessa massa de areia acumulada em profundidade que veio a se destacar um alto-fundo orientado para W. É de se supor que êsse fenômeno estivesse em preparação há vários anos devido à sobrecarga de materiais móveis, provenientes das porções $\mathrm{N}$ e $\mathrm{E}$ do semi-círculo da barra.

Em um determinado momento, aproximadamente em maio de 1948, durante uma marulhada mais forte, houve o rompimento do equil ́brio, desengatilhando-se um movimento de descarga de materiais em direção às águas mais abrigadas que se achavam a sotavento. Em 1950 o novo banco, ainda aflorante, despontou a NW dos Moleques, continuando sua marcha em direção WNW, ampliando-se progressivamente, a té formar, em 1951, um banco arenoso emergente (Foto $n^{\circ} 1$ ). 0 apareci mento do novo banco e sua rápida progressão em direção ao canal navegável atraiu simultaneamente a nossa atenção e a da Diretoria de Hidrografia e Navegação que, em principios de 1951, enviou um navio hidrográfico para proceder a uma verificação do levantamento da barra de Cananéia. De nossa parte, lembramos que sòmente em agosto de 1952 pôde a nossa Base de Pesquisas aparelhar-se convenientemente para atacar o problema. 


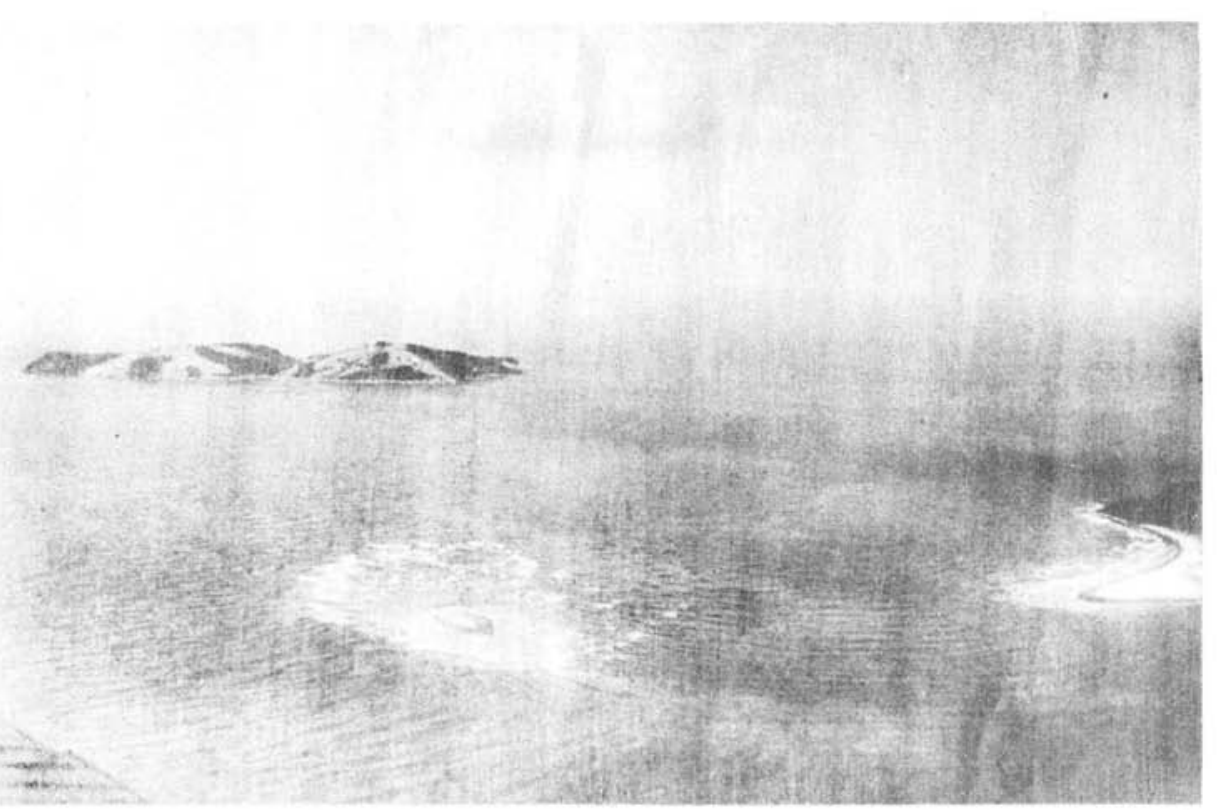

Foto a. 1 - Vista aérea da 'Iltha Nova', tirada no primeiro semestre de 1953, olhando para SE. 0 grande banco, que se achava nas imediatas proximidades dos 'Moleques', já apresentava nessa época uma parte emergente. A direita a Ponta de Itacurussá cora o esboço de esporão arenoso. 0 canal do Sul ainda era largo e perfeitamente navegável. No segundo plano acha-se a llha de Bom Abrigo. (Foto zentilmente cedida pelo Dr. Evaldo Foz)

Nessa época fizemos o primeiro levantamento topográfico da "Ilha Nova" e do esporão da Ponta de Itacurussá. Para as observações dos deslocamentos das duas neo-formações instalamos uma série de pontos de contrôle, tanto na "Ilha Nova" como no esporão. Ésses pontos consistiam numa série de marcos colocados sôbre linhas de visada que irradiavam de um ponto central onde havia sido erigida uma pirâmide geodésica - uma na ilha e outra no esporão. Por meio de um teodolito fizemos a amarração dos marcos às pirâmides e destas a uma outra pirâmide situada na Ilha do Cardoso nas proximidades do setor IV. A pirâmide da "Ilha Nova", devido ao avanço desta, teve que ser deslocada quatro vezes (vide Foto $\mathrm{n}^{\circ} 2$ ). A pirâmide situada no esporão não sofreu nenhuma alteração durante todo o tempo das observações. Para os trabalhos de topografia e sondagem escolhemos sempre os períodos de maré baixa de quadratura, fazendo nessa ocasião a observação e registro dos movimentos dos baixios e progresso do assoreamento do canal.

Com o aparecimento e deslocamento da "Ilha Nova" processou-se, rápida e simultaneamente, em tôda a região da barra, uma série de 


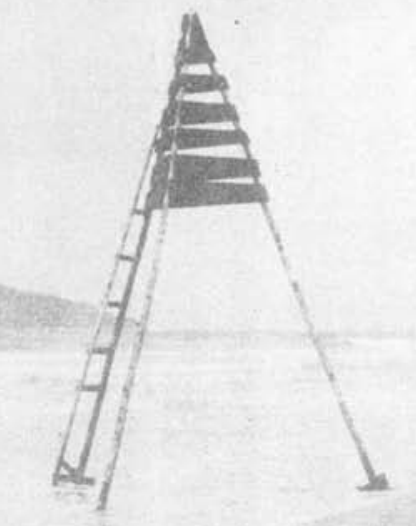

Foto V.Sadowaky, 195:

Foto n. 2 . Marco topográfico da 'Ilba Nova' por ocasião de um dos deslocamentos da ilha. No fando a Ilho ór

Bom Abrizo, vista na direção de SE.

modificações importantes. A ação topográfica, por assim dizer, mais importante do novo fenômeno, consistia no fato de que a neo-formação dirigia-se inexorávelmente para o canal de acesso navegáve] (canal do Sul ou canal dos Moleques) que, ao mesmo tempo, servia de principal escoadouro para as correntes de maré. Note-se que o novo banco, em sua marcha, após progredir através do pequeno declive submarino que limita o canal navegável, invadiu também êste úl timo. (Foto $\mathrm{n}^{\circ} \mathrm{3}$ )

0 mecanismo dêsse fenômeno nos parece evidente: - o canal tornando-se mais estreito pela pressão do banco, comprimia as fortes correntes de fluxo e refluxo da maré, as quais iam corroendo, desta forma, o lado oposto do referido canal, formando assim um cotovêlo. Por outro lado, o aumento de velocidade das correntes provocado pelo estrangulamento do canal, determinava uma intensificação da e rosão em seu leito, mantendo a profundidade média mais ou menos inal terada.

Em períodos de calmaria e ausência de marulhadas fortes, estabelecia-se um equilíbrio provisório entre as duas fôrças em jôgo; de um lado, as correntes de maré que procuravam manter o canal aberto, de outro, a ação do marulho forçando a marcha do banco em direção à 


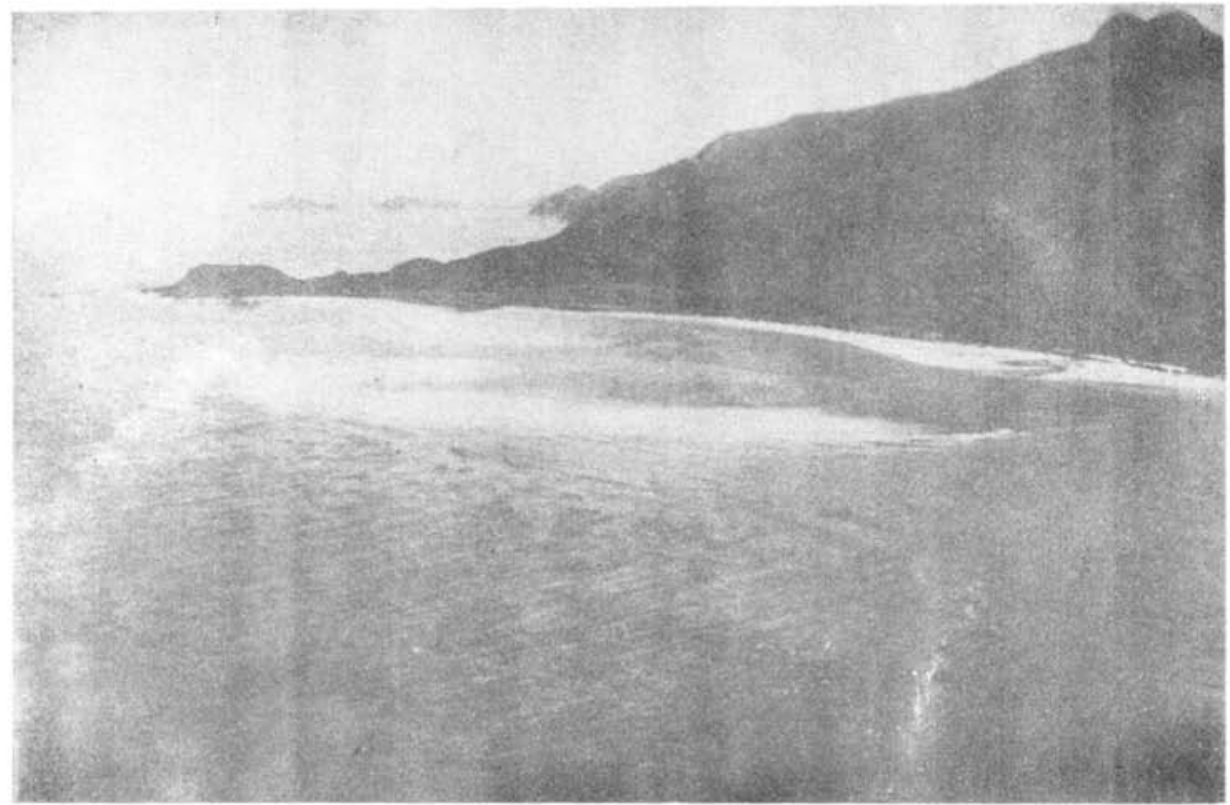

Foto n. 3 . Vista aérea tirada no primeiro semestre de 1953, na direşño S, da 'ilba Nova' e Ponta de itacurassii. Pode-se observar o acentuado crescimento e deslocamento do banco em direção a praia da llba do Cardoso. 0 estrangulamento do canal Sul, nessa época, já era bem visivel. (Foto gentilmente cedida pelo Dr. Evaldo For)

praia e, ao mesmo tempo, trazendo novos contingentes de areia. Houve vêzes em que o desenvolvimento da "Ilha Nova" limitou-se, durante vários meses consecutivos, a pequenas modificações de sua margem E, e a um alongamento na direção NNW. Nêsses períodos a itha chegou a atingir, no seu ponto mais alto, a altura aproximada de $2 \mathrm{~m}$, havendo mesmo o aparecimento de uma vegetação pioneira (Foto $n^{\circ} 4$ ).

Sobrevindo porém um período de máu tempo e mar agitado rompia-se logo o frágil equilf́brio, sobretudo nas horas de maré enchente. Nêsse instante, então, as vagas, de roldão, passavam por cima da própria ilha, reduzindo sua largura e fazendo aumentar simultaneamente seu comprimento.

O esporão arenoso da Ponta de Itacurussá e sua evolução

A Ponta de Itacurussá, distante $1 \mathrm{~km}$ da neo-formação, dispõe-se perpendicularmente à linha geral da praia da Ilha do Cardoso. Dada a orientação dominante do marulho na região (NW), à reentrância 


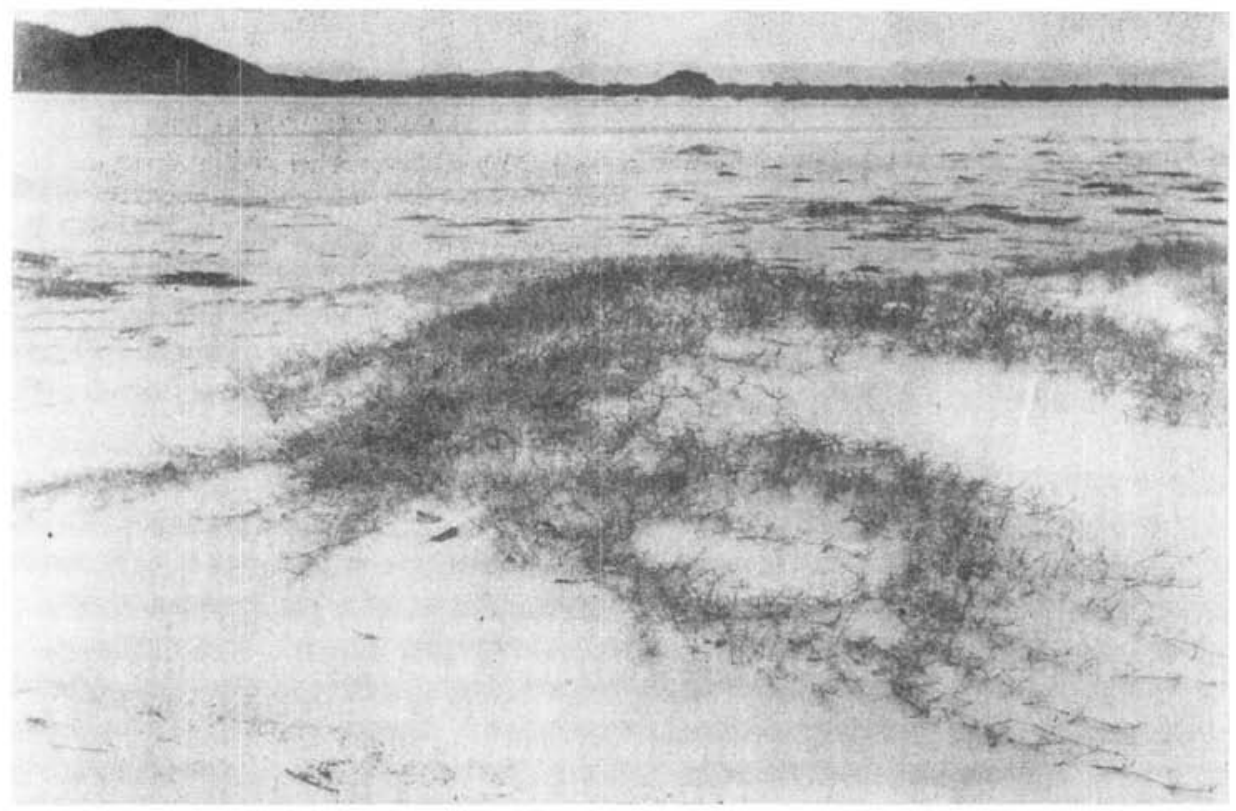

Foto a. 4 - REMIREA MARITIMA Anbl., ánica especie de vegetaço paano e balofila que coanegue resistir as coadiçoss de vida nos embrið̌es de dunas da 'llba Nova'.

formada pela ponta rochosa em relação à linha da praia, constituia uma espécie de ponto morto para a circulação das águas, tornando-se uma zona típica para processos de assoreamento. Desta forma, tendo como ponto de amarração a face $\mathrm{N}$ da Ponta de Itacurussá, um embrião de restinga se destacou e progrediu na forma clássica dos esporões de restingas (*). As aguadas provindas dos morros vizinhos passaram a desembocar, através minúsculo riacho, na faixa situada entre a novel restinga e a linha de praias mais antiga da Ilha do Cardoso. Grandes massas de areias al 1 acumuladas fizeram com que ràpidamente o esboço de esporão se transformasse em uma verdadeira restinga, que caminhou paralelamente à linha de costas preexistente na planície costeira da Ilha do Cardoso.

\section{A formação da restinga e da lagôa}

No fim de nosso primeiro período de observações (1/5/1953) achava-se a parte $\mathrm{S}$ da "Ilha Nova" ainda separada da língua arenosa pelo canal dos Moleques, que nessa época, ainda era navegável e tinha uma largura de cêrca de 100 metros. Pouco tempo depois

(*) - Veja-se também uma bరీa descrị̧ão dêsse processo em J.J. Bigarella, 1949 , p. 114. 

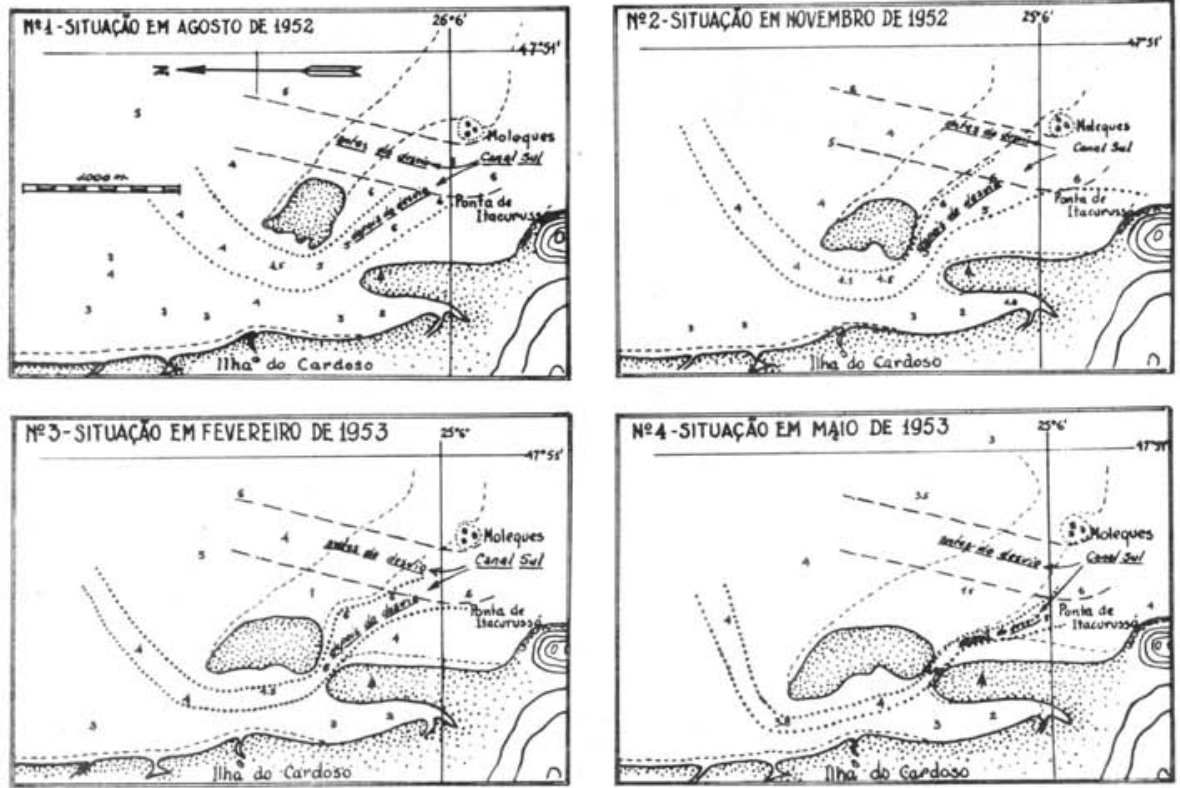

Fig. 1 - Aspecto da região por ocasião do primeiro levantamento efetuado.

Figs. 2, 3 e 4 - Progressão da 'Ilha Nova', crescimento do esporão e estrangulamento do Canal do Sul.

iniciou-se a segunda fase do fenômeno que estamos descrevendo. A W e ao $\mathrm{N}$ dos Moleques começou a acentuar-se a acumulação dos materiais móveis que, na sua progressão em direção ao oriente, assoreavam parcialmente o leito do canal navegável e tôda a parte $\mathrm{S}$ da concavidade aí existente entre os rochedos e a nova língua de areia. Êsse assoreamento foi bastante para enfraquecer sensívelmente a pressão das correntes de maré e de arrasto, contribuindo ainda com grandes contingentes de materiais móveis para o estrangulamento final do canal existente.

Com a fusão da língua de areia com a "Ilha Nova" e o desaparecimento do canal terminou a segunda fase e iniciou-se uma terceira, com a incorporação definitiva da neo-formação à praia da Ilha do Cardoso. Formou-se, então, um longo cordão litorâneo que enfeixa uma pequena baía de águas calmas. Como consequência assistimos agora às seguintes modificações finais: a) - A extremidade $\mathrm{N}$ da nova restinga aumentou consideràvelmente de comprimento, diminuindo a sua largura; b) - Essa mesma extremidade atingiu a praia da Ilha do Cardoso, fechando a pequena baía que se transformou em lagôa - lagôa de restinga semelhante às que existem mais no interior da ilha, em 

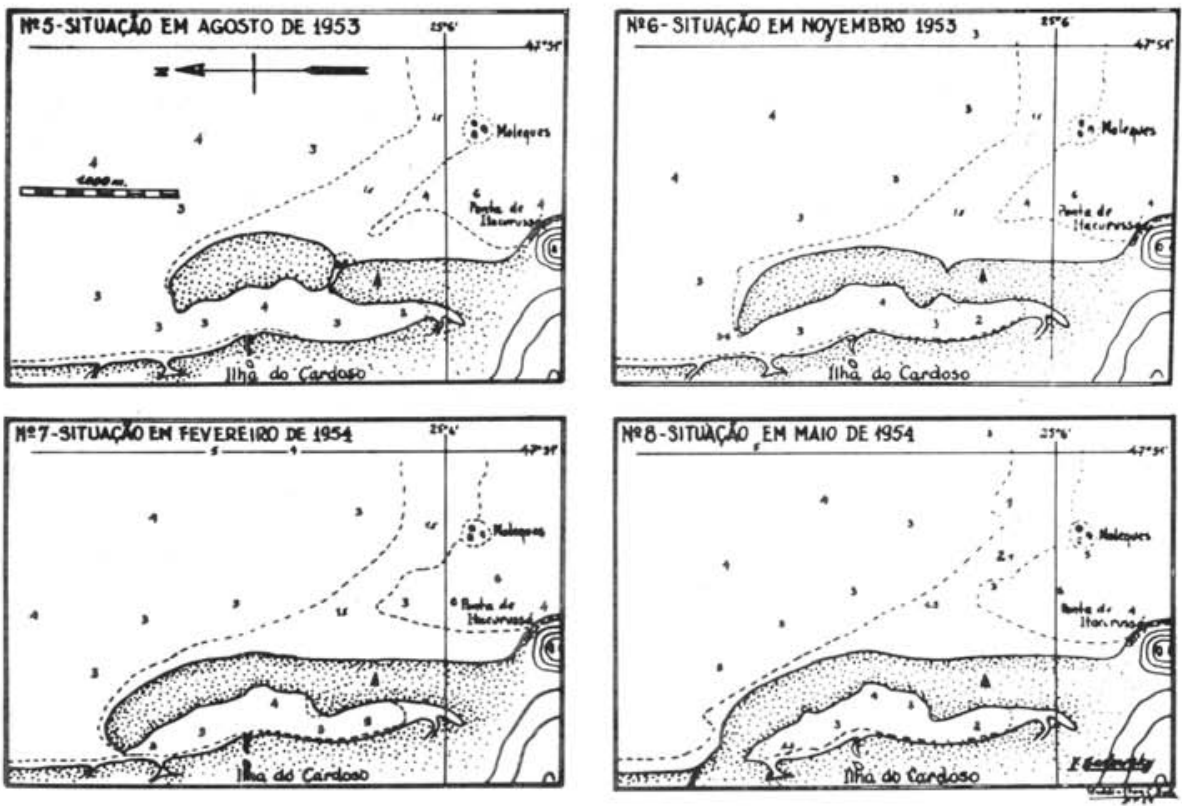

Figs. 5, 6, 7 e 8 - Formação da restinga, fechamento da laguna e retilinizaçäo da costa.

franco processo de colmatagem. A nova lagôa servindo de escoadouro para vários pequenos riachos irá progressivamente diminuir de salinidade e receber sedimentos finos, de caráter aluvial, até seu completo entulhamento; c) - A restinga, continuando a "deslisar" sôbre si mesma irá estreitar a lagôa até o momento em que um novo cordão costeiro venha se tornar suficientemente al to para resistir aos ataques do marulho.

0 mecanismo de formação daplanície litorânea da Ilha do Cardoso é nìtidamente visível na Foto $\mathrm{n}^{\circ}$, onde se observa uma série de feixes de restingas paralelos, cobertos de vegetação e separados por depressões pantanosas. É lícito supor que êsses cordões tenham sido formados, em épocas passadas, por um processo semelhante ao descrito nas páginas anteriores, e que deu origem à "Ilha Nova" e restinga subsequente.

Para retratar a marcha da conjugação dos dois núcleos de acumulações arenosas escolhemos oito fases caracteristicas, que se acham representadas pelos "croquis" e que correspondem a intervalos de 3 meses, desde 1952 até 1954. Após a fusão da restinga com o banco arenoso ilhado houve uma transfiguração final e bastante rápida do contôrno externo da ex-Ilha Nova, fato que se traduziu por uma retilinização da nova linha de costas (Figs. $n^{\circ} 1-8$ ). 


\section{OS ALTOS-FUNDOS E OS CANAIS DE ACESSO DA BARRA DE CANANÉIA}

O estudo dos canais secundários e da configuração dos altos-fundos da barra de Cananéia tem uma importância prática maior do que o próprio estudo geral do canal principal de acesso à regi ão lagunar. Isto porque na realidade, para a navegação, são os pequenos canais submarinos que interessam, como via de acesso ao porto e suas adjacências. 0 gênero de vida dos "práticos" liga-se exclusivamente ao fato de existirem canais submarinos de orientação variável na porção externa da entrada da barra, em relação aos quais apenas o pessoal mais experiente da região pode ter um conhecimento empírico, que permita uma circulação mais segura. Tais fatos, aliás, são peculiares a muitos outros pontos de barras rasas e canais múl tiplos, sujeitos a variações periódicas, existentes na fachada costeira do Brasil. Foi esta a principal razão que nos animou a orientar nossas pesquisas nêsse sentido, e que possibilitou a apresentação dos primeiros resultados a que chegamos nesta úl tima parte do presente trabalho.

A entrada da barra de Cananéia possue uma auréola de sedimentos arenosos de caráter muito instavel, os quais apresentam grande variabilidade em relação aos canais submarinos que sulcam os depósitos movediços regionais. Pelo canal principal de acesso à região lagunar passa uma grande massa de águas, resultante do jôgo das correntes de maré, que permanentemente tende a seccionar os embriões de restingas que se esboçam em tôrno da porção externa da barra. Há na realidade um conflito constante entre a correnteza da maré e a ação dinâmica das vagas que tendem ao fechamento dos canais pela excessiva sedimentação arenosa.

Antonio Paulino de Almeida (1938), tendo consultado diversos trabalhos antigos feitos por Pero Lopes de Souza, Gabriel Soares (1578), capitão-tenente Tinoco Junior, e Milliet de Saint-Adolphe, escreveu: "Portanto o caminho citado pelos escritores em seus roteiros, não é sempre o mesmo, variando de acôrdo com a mudança dos bancos de areia ahi existentes..."(p. 52). Em seguida o autor chega à conclusão de que, baseando-se nas observações efetuadas pelos antigos navegantes, podem ser presumidas três vias gerais de acesso à barra: - o canal do Norte, o de $\mathrm{E}$ ou do meio, e o do $\mathrm{S}$, ou dos Moleques; dos quais os dois últimos foram sempre os mais constantes. Sôbre a passagem da barra de Cananéia encontramos igualmente em R.Avé-Lallemant (1858, p. 323, da ed.1953) o seguinte: "O piloto conduziu-nos pela barra e recifes fora para o mar aberto até a 


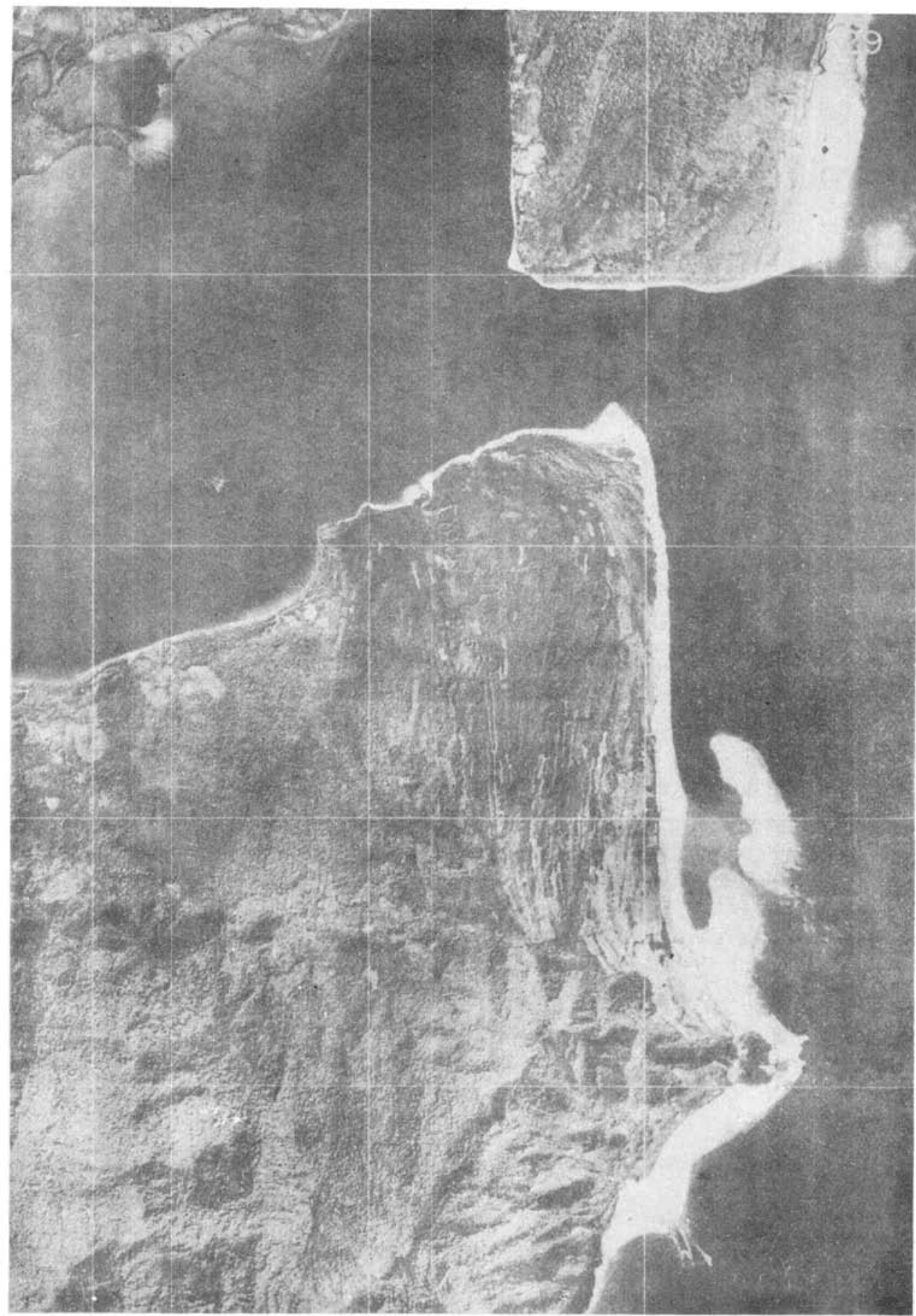

Foto a. 5 - Vista aérea da regillo eatudada. Observem-se os feixes de restingas an Ilba do Cardoso. (Foto zentilmente cedida pelo Dep. Nac. de Obras e Sacamento) 


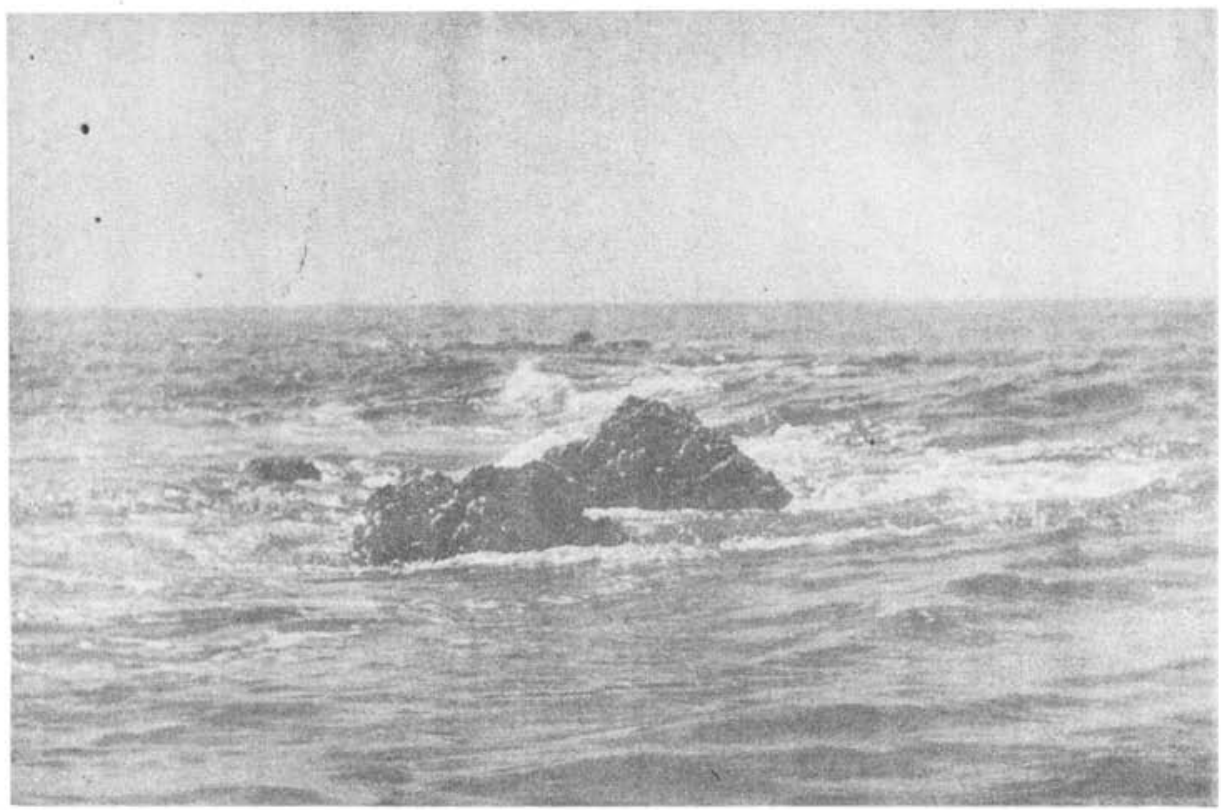

Foto V.Sadowsky, 1954.

Foto a. 6 - Vista dos 'Moleques' aa direçắo de NE, com mar calmo e maŕ́ baixa. Ém seguado plano vê-se outro cabeşo descoberto.

Ilha de Bom Abrigo". 0 único trecho da região onde o autor poderia ter visto "recifes" na barra é justamente na passagem pelo canal do $\mathrm{S}$, de um lado, os rochedos Moleques, e do outro, a Ponta de Itacurussá. (Fotos 6 e 7 ).

O Roteiro do Brasil (Ed. de 1948, p. 328) referindo-se aos canais navegáveis da barra de Cananéia diz o seguinte: "Ocanal E-W, situado entre dois extensos bancos de areia, tem a largura de cêrca 300 metros; transposto êste, as profundidades aumentam até 24 metros. Houve comunicação, no entanto, em 1940, de éstar êste canal sendo obstruido pelos bancos de areia.

0 canal dos Moleques, na direção N-S, entre a Ponta de Itacurussá e as pedras Moleques, tem profundidades de 3,2 a 6 metros e é o único utilizado pelos navios últimamente."

No início de nossas observações encontramos o canal $\mathrm{S}$ em pleno desenvolvimento, possibilitando uma larga e relativamente profunda passagem para a cabotagem e para tôda a correnteza reversível entre o oceano e a região lagunar. (Foto $n^{\circ} 1$ ) Os outros dois canais, situados a $\mathrm{E}$ e a $\mathrm{N}$ do Baixio de Fora, davam vazão a correntezas menores, tendendo para um entupimento completo, ainda que de caráter temporário, conforme foi verificado por observações poste- 


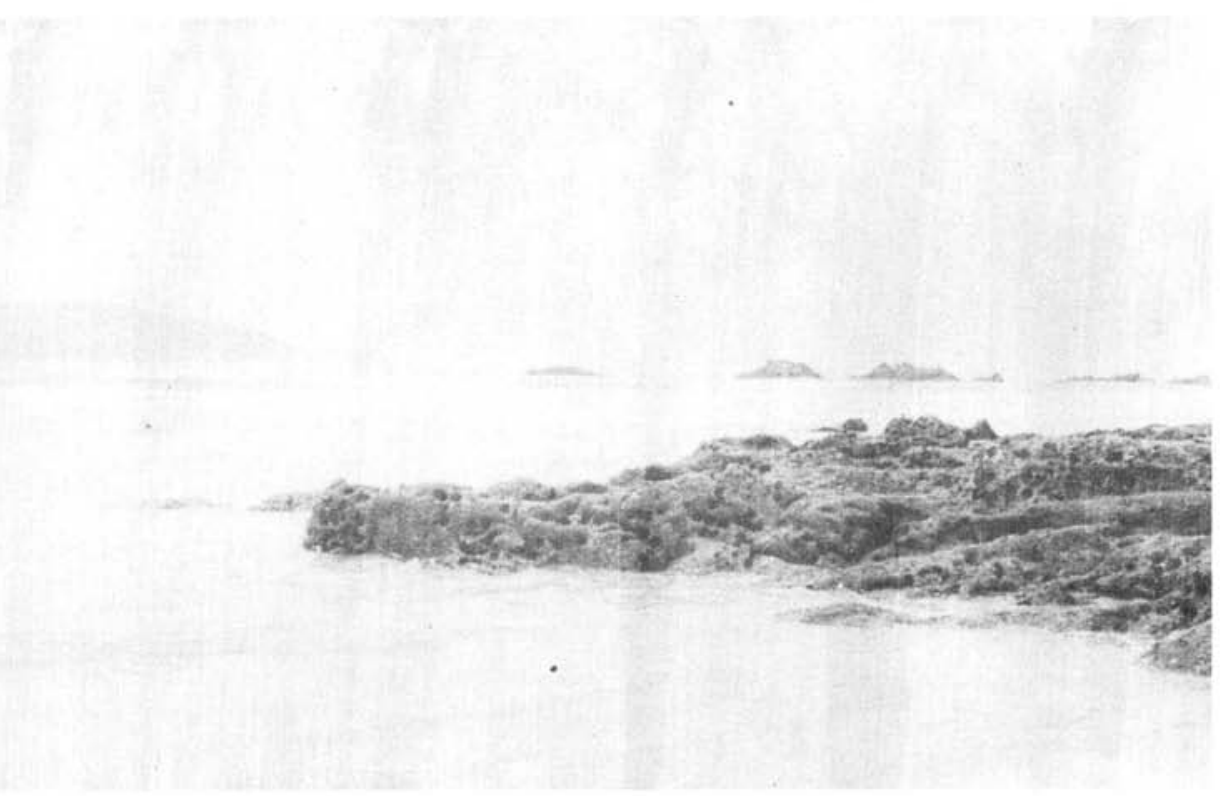

Foto W.Hein, 1954.

Foto n. 7 - Formaçōes rochosas da Ponta de Itacurussá (filitos proterozoicos da série Sảo Roque) com orificios

abertos por ouriços do mar,ECHINOMETRA LOCUNTERL. e LYTECHINUS VARIEGATUS Leske.

riores. A acumulação das massas de areia em tôrno da extremidade $\mathrm{S}$ dos altos-fundos da barra ("Ilha Nova") e sua movimentação em direção à costa provocou o estrangulamento do canal $\mathrm{S}$ até atingir à situação extrema de fechamento total. Concomitantemente esboçou-se a abertura dos dois outros canais, que até então permaneciam semi-obstruidos. Essas modificações da barra permitem-nos supor que os fenômenos acima relatados não são de ordem definitiva. 0 banco arenoso que provocou o estrangulamento do canal $\mathrm{S}$ continuou a sua marcha, vindo a encostar-se à praia da Ilha do Cardoso. Com isto os sedimentos que vinculam êsse banco aos altos-fundos dos Moleques passaram a apresentar vários pontos de fragilidade, devido ao seu adelgaçamento, possibilitando a eventual reconstrução do canal primitivo durante a intervenção de fortes tempestades do quadrante S. Tais tempestades podem executar o seccionamento do cordão arenoso sulmarino em poucos dias, reabrindo novamente o canal. Processar-se-á então a volta ao estágio inicial, sendo que os canais $\mathrm{N}$ e E perderão gradualmente a correnteza, ficando novamente ameaçados de obstrução progressiva. Parece ser, portanto, um fenômeno de caráter periódico. Pela Fig. B vemos que o Pontal de Fora na Ilha Comprida é prolongado, 
na sua porção submersa, por uma extensa línqua de areia com profundidades médias de $1,2 \mathrm{~m}$. Na extremidade dessa formação, e tendo uma orientação geral para NE, acha-se uma passagem relativamente larga denominada Canal do Norte, com profundidades de cêrca de $4 \mathrm{~m}$. Na sua embocadura prumam-se $11-12 \mathrm{~m}$, com fundos de natureza lodosa.

O canal, na sua parte E, é limitado por uma série de altos- fundos que, mais adiante, tomam uma forma convexa e se orientam bruscamente, na sua parte média, para W, terminando por extenso cabeço arenoso chamado pelos práticos locais de "Ponta" ou "Cabeça do Gigante". Essa convexidade é interrompida na sua parte SE por uma estreita e sinuosa passagem, prumando $3,5 \mathrm{~m}$, conhecida pelo nome de Canal de Leste.

A "Ponta do Gigante" é continuada a E por outros altos-fundos, que formam uma convexidade menor e alcançam os Moleques na sua extremidade S. Um prolongamento dêsses altos-fundos continua até a nova restinga ligada à praia da Ilha do Cardoso.

Comparando os contornos dos bancos da barra conforme foram esboçados no mapa da Marinha ( ${ }^{\circ}$ 1703, de 1938), com a atual situação, percebem-se as seguintes modificações importantes: o banco que constitue o prolongamento submerso do Pontal de Fora e que, no mapa, tem a forma de uma língua extensa, atingindo o $\mathrm{N}$ do Canal de Leste, sofreu com o tempo uma notável deformação. Deslocando-se em direção a E, tomou uma forma convexa, sendo interrompido ao $\mathrm{N}$ pelo canal do mesmo nome. Na zona onde se achava anteriormente êste banco, prumam-se atualmente profundidades que variam de 5 a $7 \mathrm{~m}$. O Canal de Leste, que em 1938 era largo e apresentava profundidades variáveis de 5-6 e 8m, sofreu acentuado assoreamento e deformação. A faixa dos altos-fundos que se segue ao canal e se prolongava em direção a $S W$ até os Moleques, também foi alvo de uma série de alterações importantes. A S do Canal de Leste apareceu um al to banco - a "Ponta do Gigante", na denominação local. A longa corôa que se acha assinalada no mapa a ENE dos Moleques, com prumos de $0,90 \mathrm{~m}$, não mais existe.

Pelo que nos foi dado observar nos últimos anos, existe um transporte de materiais móveis em direção a $W$, nêsse trecho, o que nos permite supor que os elementos formadores da corôa assinalada acima tenham ido agregar-se à neo-formação da "Ilha Nova".

Terminando êste trabalho desejamos testemunhar nossos sinceros agradecimentos ao Prof. W. Besnard, pelas suas valiosas sugestões, e ao Prof. Aziz N.Ab'Sáber, pelo auxílio prestado na revisão do manuscrito. 


\section{RE $\mathbf{S}$ U 0}

N6ste trabalho, o autor conalúe investigaróes relativas às nodifioagões ocorridas na barra de Cananfia e regiōes oirounvizinhag.

Na primeira parte apresenta dados colhidos, nêste ultimo ano, sôbre modifioacões verificadas na costa, demonstrando con a apresentagão de doís gráficos e um esquêma, o desenvolvimento dos fenẑmenos de erosão ou acumul agão.

Na segunda parte é feita a desorição da gênese de una restinga o de una lagôa, várias fases, dooumentadas por "oroquis", fotografias locais e áreas.

Na terceira parte tecem-se consideragões sరobre a variagão dos canais seoundários da barra, llustrando "oroquis".

\section{AB\& TRACT}

The author conoludes his investigations ocnoerning the rodifioations ocourring at the bar and ontrance of the lagoon region of Cenanbia (State of S. Paulo, Brasil).

In the first part of the peper data gathered in the last year (1954) are presented and by means of two graphs and a sketch the progress of the phenomens of orosion and acoretion are demonstrated.

In the second part a description, in various phases, of the development of a "restinga" (spit or bar of sand) is given, dooumented by sketohes and several photos.

In the third part considerations are made about the variation of the bar secondary channels and an interpretation of the process is given.

\section{BIBLIOGRAFIA}

NMEIDA, ANTONIO PAUL INO DE

1988. Ilha do Bon Abrigo. Rev. do Inst. Hist. Geogr. de 8.Paulo, Vol. XXXIV, p. DO-52.

AVELLALLEMAMT, ROBERTO

1953. Viagem pelo sul do Brasil no ano de 1858. Trad. de Teodoro Cabral. Inst. Naoional do Livro, 2 vol., Rio de Janeiro.

BIGARELLA, J.

1949. Contribuigão a estudo da Planioie Sodimentar da parte Norte da Ilha de Santa Catarine. Arquivos de Blologia e Tecnologia, Vol. IV, p. 114 .

GUILCHER, A.

1950. Cours d'Notanographie. I - Norphologie, struoture ot sediments sous-marins. Eydrologie marine. 1er. faso., 125 p., Centre de Documentation Universitaire, Paris. 
GUILCHER, A. \& NICOLAS, J.

1954. Observations sur la Langue de Barbarie et le bras du Senegal aux environs de S.Louis. Bul1. d'Information, C.O.E.C., n. 6, p. 236.

MARINHA NACIONAL

1939. Mapa de Cananéia - Carta n. 1703. Levantamento efetuado pela Diretoria de Hidrografia e Navegacão. Rio de Janeiro.

1948. Roteiro do Brasil. Diretoria de Hidrografia e Navegagão. Rio de Janeiro.

RAWITSCHER, F.K.

1944. Algumas noções sôbre a vegetạão do litoral brasileiro. Bo1.Assoc. dos Geogr.Bras., n. 5, p. 24 (numeração da separata).

SADOWSKY, $V$.

1952. Observações sôbre as modificações em curso na entrada de Cananéia, de sua barra e da região adjacente. Bol. Inst. Oceanografico, t. III, fasc. 1 e 2, p. 201-208.

1953. Modificacões em curso na entrada da barra de Cananéia. Bo1. Inst. Oceanografico, t. IV, fasc. 1 e 2, p. 191-214.

SILVA, CLODOMIRO PEREIRA DA

1940. A evolução do transporte mundial: introdução a estudo dàs aquavias maritimas - O regimen das costas, particularmente no Brasil. Livro 2\%, Vol. 2, 100 p., Imprensa Oficial, S.Palo.

SILVA, PAULO DE CASTRO MOREIRA DA

1952. Estudo preliminar da propagação do marulho de leste s8bre a plataforma continental do E. de S. Paulo, e, em particular de sua refração e arrebentagâo em Cananeia. Bo1. Inst. Oceanografico t. III, fasc. 1 e 2, p. 35-38.

SILVEIRA, J. DIAS DA

1952. Fachadas Litoraneas Quentes e Umidas. Bol.Fac.Fil.Ci. e Letr. Univ.S.Paulo, Vol. 152, Geografia n. 8, p. 128. 


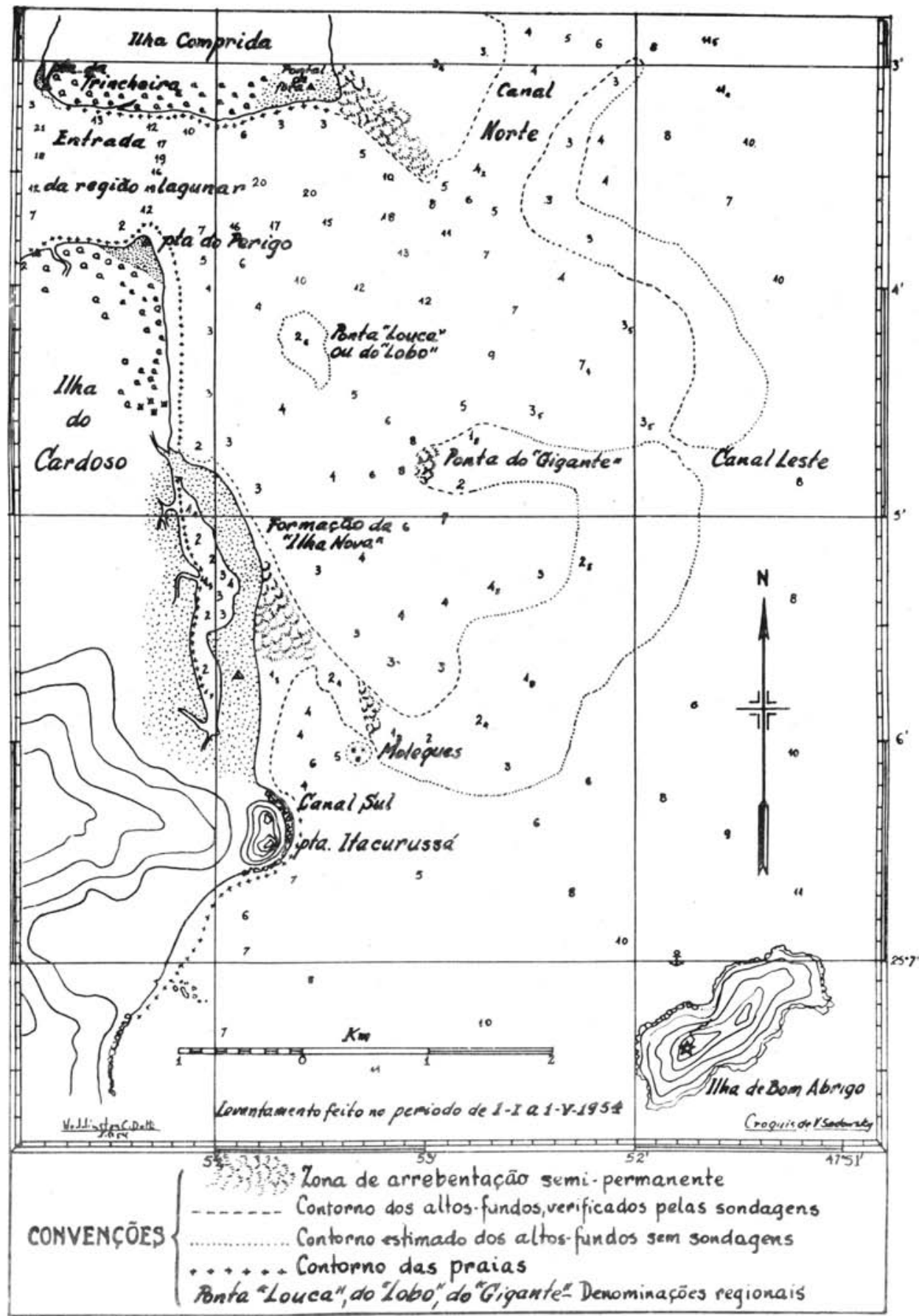

